\title{
Studies on the Proteolytic Activity of Bacteroides fragilis
}

\author{
By S. A. W. GIBSON AND G. T. MACFARLANE* \\ MRC Dunn Clinical Nutrition Centre, 100 Tennis Court Road, Cambridge CB2 1QL, UK
}

(Received 19 June 1987; revised 17 August 1987)

The proteolytic activity of the intestinal bacterium Bacteroides fragilis NCDO 2217 was cell-
bound during exponential growth, but was progressively released from the cells in stationary
phase. Proteins hydrolysed included casein, trypsin, chymotrypsin, azocasein and the proteins
in azosoya bean flour. Collagen, azocoll, elastin, gelatin, ovalbumin and bovine serum albumin
were either weakly degraded or completely refractory to proteolysis. Arylamidase activity was
exhibited against leucine $p$-nitroanilide (LPNA), leucine $\beta$-naphthylamide, glycyl-proline $p$ -
nitroanilide and valyl-alanine $p$-nitroanilide. The bacterium grew with ammonia, peptone or
casein as sole nitrogen source. Azocasein- and LPNA-hydrolysing activities were consistently
higher when grown on casein. Cell-bound protease activity increased concomitantly with
growth rate in both carbon- and nitrogen-limited continuous culture. Leucine arylamidase
activity was also growth-rate-dependent, being 3 -fold greater at $D=0.18 \mathrm{~h}^{-1}$ compared to
$D=0.03 \mathrm{~h}^{-1}$. Extracellular proteolytic activity was only detected at low growth rates,
accounting for about $25 \%$ of total protease activity.

INTRODUCTION

Growth of saccharolytic bacteria in the human large intestine appears to be effectively limited by the availability of fermentable carbohydrate, while comparatively high levels of protein and ammonia occur throughout the length of the gut (Macfarlane et al., 1986). Intestinal contents are strongly proteolytic and although much of this activity is undoubtedly pancreatic in origin (Bohe et al., 1983), recent evidence has indicated that colonic bacteria, particularly Bacteroides spp., may contribute substantially to protein breakdown (Macfarlane et al., 1985, 1986; Macfarlane \& Allison, 1986). At present, however, little is known concerning the factors that control bacterial proteolysis in the large gut, or of the significance of this process in the microbial ecology of the colon. Bacteroides fragilis group organisms are the numerically predominant anaerobes in the large gut, and as such account for about $30 \%$ of bacteria isolated from faeces (Macy \& Probst, 1979; Salyers, 1984). The major activity of these bacteria in the colon appears to be that of polysaccharide degradation, a process that has been extensively studied (Salyers et al., 1977; Salyers \& O'Brien, 1980; Gherardini et al., 1985). The proteolytic capabilities of colonic bacteroides have so far received little attention, however.

Preliminary investigations in our laboratory indicated that different strains from the Bacteroides fragilis group possessed similar proteolytic activities, although the levels of protease activity varied considerably between individual species (Cummings et al., 1986). In this paper, we report the results of further studies on the proteolytic activity of Bacteroides fragilis NCDO 2217.

\section{METHODS}

Organism. Bacteroides fragilis NCDO 2217 (Loesche et al., 1964) was obtained from the National Institute for Research in Dairying, Shinfield, Reading, UK. Confirmation of the identity of the bacterium was obtained using procedures described by Holdeman et al. (1977).

\footnotetext{
Abbreviations: LPNA, leucine $p$-nitroanilide; N-CBZ-, N-carbobenzoxy-; VAPNA, valyl-alanine $p$ nitroanilide; VFA, volatile fatty acids.
} 
Location of proteases. Bacteria were grown in batch culture on Wilkins-Chalgren broth in 11 fermenters. Anaerobic conditions were maintained by sparging cultures with a gas mixture containing $10 \% \mathrm{H}_{2}, 10 \% \mathrm{CO}_{2}$ and $80 \% \mathrm{~N}_{2}$. Temperature $\left(37^{\circ} \mathrm{C}\right)$ and $\mathrm{pH}(6 \cdot 8)$ were controlled as described by Macfarlane \& Englyst (1986). Bacterial growth was determined by measuring the optical density at $650 \mathrm{~nm}$. For measurement of proteolytic activity, $20 \mathrm{ml}$ vols of culture were centrifuged at $20000 \mathrm{~g}$ for $30 \mathrm{~min}$. The cell pellets were washed and resuspended in $20 \mathrm{ml}$ anaerobic $0 \cdot 1 \mathrm{M}$-sodium phosphate buffer, $\mathrm{pH} \mathrm{7 \cdot 4}$. Protease activities were determined in the resuspended cells and cell-free culture supernatants. Protease activities were measured as follows. Samples ( $1 \mathrm{ml})$ were dispensed in triplicate into $1.5 \mathrm{ml}$ capacity Eppendorf tubes and mixed with $0.2 \mathrm{ml}$ phosphate buffer. The reactions were begun by the addition of $0.3 \mathrm{ml}$ azocasein stock solution, which gave an initial substrate concentration of $10 \mathrm{mg} \mathrm{ml}^{-1}$. The tubes were capped and incubated for $2 \mathrm{~h}$ at $37^{\circ} \mathrm{C}$. The reactions were stopped by transferring the tube contents into centrifuge tubes that contained $1 \mathrm{ml} 10 \%(\mathrm{w} / \mathrm{v}) \mathrm{TCA}$. Control tubes were incubated as above, but without azocasein, which was added after inactivation of the sample with TC.A. After samples had been allowed to stand for $30 \mathrm{~min}$, they were centrifuged at $27000 \mathrm{~g}$ for $8 \mathrm{~min}$. Thereafter, $1 \mathrm{ml}$ of supernatant was mixed with an equal volume of $1.0 \mathrm{M}-\mathrm{NaOH}$. The absorbance of this solution was then read at $450 \mathrm{~nm}$.

Hydrolysis of different protein substrates. B. fragilis was grown and harvested as described above. Cells from $200 \mathrm{ml}$ of culture were resuspended and washed twice in $100 \mathrm{ml}$ phosphate buffer. The ability of the cell-bound proteases to hydrolyse a range of native and diazotized proteins was then examined. Samples of bacteria $(5 \mathrm{ml})$ were added to $5 \mathrm{ml}$ of a solution containing one of the following protein substrates (all $2 \%, \mathrm{w} / \mathrm{v}$ ): casein, BSA grade $\mathrm{V}$, ovalbumin grade $\mathrm{V}$, collagen grade $\mathrm{V}$, gelatin, trypsin, chymotrypsin, azocoll, azoalbumin or azosoya bean flour. Bacteria were incubated with the proteins at $37^{\circ} \mathrm{C}$. Samples $(1 \mathrm{ml})$ were taken at zero time, and at 2,4 and $6 \mathrm{~h}$, and added to $1 \mathrm{ml} \mathrm{10 \% (w/v)} \mathrm{TCA.} \mathrm{Peptides} \mathrm{released} \mathrm{from} \mathrm{native} \mathrm{proteins} \mathrm{were} \mathrm{measured} \mathrm{using} \mathrm{the} \mathrm{Lowry}$ method. Dye released from the diazotized proteins was measured spectrophotometrically at $450 \mathrm{~nm}$ as described previously. The release of orcein dye from elastin-orcein was determined using the method of Appel (1984a). Breakdown of trypsin and chymotrypsin was followed by the decrease in the activities of these enzymes towards their $p$-nitroanilide substrates (benzoyl-arginine $p$-nitroanilide and glutaryl-phenylalanine $p$-nitroanilide respectively) during incubation with bacteria. Boiled cells were used as controls.

Hydrolysis of p-nitroanilide substrates. The ability of $B$. fragilis proteases to hydrolyse a range of synthetic $p$ nitroanilide substrates was investigated using a modification of the method of Appel $(1984 \mathrm{~b})$. The following Lamino acid $p$-nitroanilides were tested : benzoyl-arginine $p$-nitroanilide, leucine $p$-nitroanilide (LPNA), valylalanine $p$-nitroanilide (VAPNA), glutaryl-phenylalanine $p$-nitroanilide, glutamyl $p$-nitroanilide, succinyl-alanylalanyl-alanine $p$-nitroanilide, benzyl-cysteine $p$-nitroanilide, glycyl-proline $p$-nitroanilide, benzyl-tyrosine $p$ nitroanilide and lysine $p$-nitroanilide. Washed cells of $B$. fragilis were obtained as described above, except that the bacteria were resuspended in $0.05 \mathrm{M}-\mathrm{Tris} / \mathrm{HCl}, \mathrm{pH} 7.4$. Samples $(0.5 \mathrm{ml})$ were dispensed in triplicate into $1.5 \mathrm{ml}$ capacity Eppendorf tubes. Samples $(1.0 \mathrm{ml})$ of substrate $(1.2 \mathrm{~mm}$ in $0.05 \mathrm{M}$-Tris $/ \mathrm{HCl}, \mathrm{pH} 7.4)$ were then added to the tubes to start the reaction. The capped tubes were incubated at $37^{\circ} \mathrm{C}$ for $15 \mathrm{~min}$ in the case of VAPNA, and $1 \mathrm{~h}$ for the other $p$-nitroanilides. Reactions were stopped by the addition of $0 \cdot 1 \mathrm{ml}$ perchloric acid $(70 \%$, w $/ \mathrm{v})$. After standing for $30 \mathrm{~min}$ the samples were centrifuged at $11600 \mathrm{~g}$ for $10 \mathrm{~min}$. The supernatant was retained. $p$-Nitroaniline released by hydrolysis of the synthetic substrates was measured by diazotization (Appel, 1984b).

Hydrolysis of $\beta$-naphthylamide substrates. The ability of $B$. fragilis to hydrolyse the following substrates was tested: alanine $\beta$-naphthylamide, leucine $\beta$-naphthylamide, serine $\beta$-naphthylamide, pyrrolidonyl $\beta$-naphthylamide, proline $\beta$-naphthylamide, cystine $\beta$-naphthylamide and valine- $\beta$-naphthylamide. Release of $\beta$-naphthylamine, which indicated a positive reaction, was determined using procedures for measuring leucineaminopeptidase activity, described in Sigma Technical Bulletin 251.

Carboxypeptidase measurements. These assays were done using the colorimetric method described by Appel $(1984 c)$ in which the amino acid or peptide released by C-terminal hydrolysis is detected by the ninhydrin reaction. The following substrates were used: N-CBZ-glycyl-alanine, N-CBZ-glutamyl-phenylalanine, N-CBZ-valylalanine methyl ester, N-CBZ-proline and N-CBZ-aspartate.

Utilization of casein by $B$. fragilis. The bacteria were grown in batch culture as before. The mineral salts medium used contained $\left(l^{-1}\right)$ : glucose, $10.0 \mathrm{~g} ; \mathrm{KH}_{2} \mathrm{PO}_{4}, 4.0 \mathrm{~g} ; \mathrm{Na}_{2} \mathrm{HPO}_{4}, 2.0 \mathrm{~g} ; \mathrm{NaCl}, 9.0 \mathrm{~g}$; cysteine, $0.8 \mathrm{~g} ; \mathrm{NaHCO}_{3}$, $1.5 \mathrm{~g} ; \mathrm{CaCl}_{2}, 0 \cdot 1 \mathrm{~g} ; \mathrm{MgCl}_{2}, 0 \cdot 15 \mathrm{~g} ; \mathrm{MnCl}_{2}, 0.10 \mathrm{~g} ; \mathrm{CoCl}_{2}, 0.10 \mathrm{~g} ; \mathrm{FeSO}_{4}, 1.0 \mathrm{mg}$; haemin, $5.0 \mathrm{mg}$; vitamin $\mathrm{B}_{12}$, $0.5 \mathrm{mg}$. Casein $(0.5 \%)$ was the sole nitrogen source. Bacterial growth was followed by direct counting methods using a Neubauer counting chamber (Cruickshank, 1965). Protein and peptides were measured as follows. Samples were centrifuged at $20000 \mathrm{~g}$ for $30 \mathrm{~min}$ to remove bacteria. The supernatants were retained and divided into two equal portions, one of which was treated with an equal volume of $10 \%(w / v)$ TCA. The other was added to an equal volume of $0 \cdot 1 \mathrm{M}$-sodium phosphate buffer, $\mathrm{pH} 7 \cdot 4$ and was used to measure the soluble protein remaining in the culture. The TCA-treated samples were allowed to stand for $30 \mathrm{~min}$ at room temperature, then centrifuged at $27000 \mathrm{~g}$ for $10 \mathrm{~min}$. The resulting supernatants were used for measurement of TCA-soluble peptides and the pellets were resuspended in phosphate buffer for determination of TCA-insoluble protein. Protein and peptides were measured by the Lowry method. 
Effect of nitrogen source on protease and arylamidase activity. Bacteria were grown in batch culture on the mineral salts medium containing $\mathrm{NH}_{4} \mathrm{Cl}$, peptone water or casein as nitrogen source (all $0.5 \%$ ). In experiments where the effects of protein and peptides on proteolysis were studied, casein, BSA or peptone $(5 \%, \mathrm{w} / \mathrm{v})$ were dissolved in $0.05 \mathrm{M}$-Tris/ $\mathrm{HCl}, \mathrm{pH} 7 \cdot 4$. Samples $(75,150,225,300$ or $450 \mu \mathrm{l})$ of each solution were dispensed in triplicate into $1.5 \mathrm{ml}$ capacity Eppendorf tubes containing 500, 425, 350, 275, 200 or $50 \mu$ l of the Tris buffer. The washed bacteria $(0.5 \mathrm{ml})$ were then added to the tubes and the mixtures were incubated for $15 \mathrm{~min}$ at $37^{\circ} \mathrm{C}$. The reactions were initiated by addition of the Tris buffer $(0.5 \mathrm{ml})$ containing VAPNA or LPNA (both $2.4 \mathrm{~mm}$ ). Arylamidase activities were determined as described above.

Effect of ammonia, volatile fatty acids and haemin on protease and arylamidase activity. Batch cultures of $B$. fragilis were grown on mineral salts medium in experiments where the effect of ammonia on protease production was studied and in Wilkins-Chalgren broth to determine the effect of volatile fatty acids (VFA). Filter sterilized fatty acid mixtures (acetate, propionate and butyrate, molar ratio $2: 1: 1$ ) were added to the medium after autoclaving. To determine its influence on protease production, haemin was omitted from the mineral salts medium. Fermentation products were measured using the methods of Holdeman et al. (1977).

Continuous culture studies. Bacteria were grown in continuous culture using 0.51 (working volume) glass chemostats. Temperature $\left(37^{\circ} \mathrm{C}\right), \mathrm{pH}(6.8)$ and the maintenance of anaerobic conditions were controlled as described by Macfarlane \& Englyst (1986). The basal growth medium was the mineral salts medium described above. Glucose and $\mathrm{NH}_{4} \mathrm{Cl}$ concentrations in the carbon-limiting medium were $5 \mathrm{~g} \mathrm{l}^{-1}$ and $1 \mathrm{~g} \mathrm{l}^{-1}$ respectively, and in the nitrogen-limiting medium were $15 \mathrm{~g} \mathrm{l}^{-1}$ and $1 \mathrm{~g} \mathrm{l}^{-1}$. Bacteria were harvested by centrifugation as before. The cell-free supernatants were retained for measurement of extracellular protease and arylamidase activities. After washing, the cell pellets were used for determination of cell-bound protease and arylamidase activities.

Dry weight measurements. Cuiture dry weights were determined using methods described by Keith \& Herbert (1983).

Chemicals. Casein was obtained from BDH. All other chemicals were supplied by Sigma. Bacteriological media were purchased from Oxoid.

\section{RESULTS}

Location of proteases. B. fragilis proteases were totally cell-associated during the initial stages of growth in batch culture (Fig. 1). Cell-bound proteolytic activity increased concomitantly with growth until stationary phase was reached. As growth slowed, however, protease activity accumulated in the culture medium. This was accompanied by only a slight decrease in culture optical density and cell-bound protease activity.

Proteins hydrolysed by B. fragilis proteases. B. fragilis proteases exhibited a degree of specificity with respect to the hydrolysis of protein substrates (Table 1). Of the proteins tested, only casein, trypsin, chymotrypsin, azocasein and the proteins in azosoya bean flour were hydrolysed to any significant extent. The highly globular proteins ovalbumin, BSA and azoalbumin were poor substrates. It was considered possible that low levels of BSA hydrolysis had occurred, but had been concealed by assimilation of the peptide products by the bacteria. However, an advantage of using diazotized substrates to detect proteolysis by $B$. fragilis was that the dye released during protein breakdown was stable and was not reduced by the bacteria. The absence of dye release from azoalbumin therefore provided corroboratory evidence as to the resistance of these globular proteins to $B$. fragilis proteases. The insoluble proteins elastin, gelatin, collagen and azocoll (diazotized collagen) similarly did not serve as substrates for $B$. fragilis proteases.

Arylamidase and carboxypeptidase activities. As well as peptide bonds, some proteolytic enzymes can catalyse the hydrolysis of the amino-acyl bond between amino acids and $p$ nitroaniline or $\beta$-naphthylamine. $B$. fragilis proteases hydrolysed LPNA, VAPNA, glycylproline $p$-nitroanilide and leucine $\beta$-naphthylamide (Table 1). No activity was detected against the trypsin substrate benzoyl-arginine $p$-nitroanilide, the chymotrypsin substrate glutarylphenylalanine $p$-nitroanilide or the elastase substrate succinyl-alanyl-alanyl-alanine $p$-nitroanilide. Carboxypeptidase activity was not found against any of the N-CBZ amino acid substrates (Table 1).

Utilization of casein during growth. Casein was hydrolysed by $B$. fragilis in exponential and stationary phase cultures (Fig. 2). The proteolysis occurring during active growth did not result in the accumulation of TCA-soluble peptides in the culture medium, indicating that $B$. fragilis 

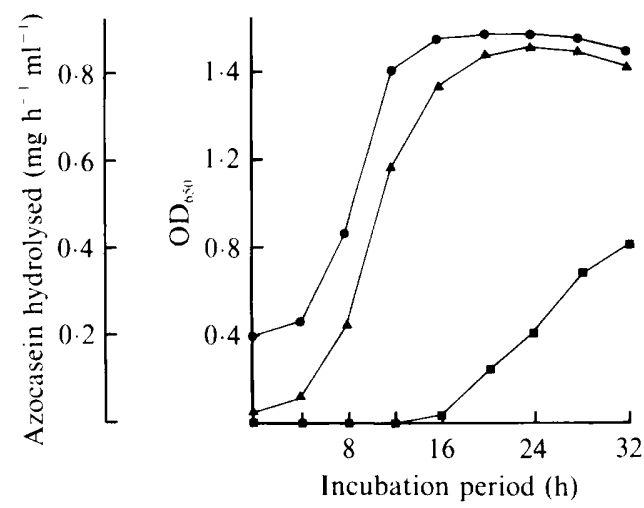

Fig. 1. Location of $\boldsymbol{B}$. fragilis proteases. $\bullet, \mathrm{OD}_{650} ; \boldsymbol{\Delta}$, cell-bound protease activity; $\mathbf{\square}$, extracellular protease activity. Data are means of three experiments.

\section{Table 1. Proteins and synthetic substrates hydrolysed by B. fragilis proteases}

Exponentially growing bacteria were harvested and washed before use in enzyme assays. Breakdown of trypsin and chymotrypsin was monitored by following the decrease in arylamidase activity against their respective substrates, benzoyl-arginine $p$-nitroanilide and glutaryl-phenylalanine $p$-nitroanilide. Results are presented as the means of between two and five experiments \pm SD, where appropriate.

\begin{tabular}{|c|c|c|c|c|c|}
\hline $\begin{array}{l}\text { Protein } \\
\text { substrate }\end{array}$ & Hydrolysis* & $\begin{array}{l}\text { Carboxypeptidase } \\
\text { substrate }\end{array}$ & Hydrolysis & Arylamidase substrate & Hydrolysis $\dagger$ \\
\hline Casein & $188 \pm 56$ & $\begin{array}{l}\mathrm{N}-\mathrm{CBZ}-\mathrm{Glycyl}- \\
\text { alanine }\end{array}$ & - & Leucine $p$-nitroanilide & $22 \cdot 3 \pm 7 \cdot 6$ \\
\hline BSA & - & $\begin{array}{l}\text { N-CBZ-Glutamyl- } \\
\text { phenylalanine }\end{array}$ & - & $\begin{array}{l}\text { Benzoyl-arginine } \\
p \text {-nitroanilide }\end{array}$ & - \\
\hline Ovalbumin & $1 \cdot 0 \pm 0.4$ & $\begin{array}{l}\mathrm{N}-\mathrm{CBZ} \text {-Valyl-alanine } \\
\text { methyl ester }\end{array}$ & - & $\begin{array}{l}\text { Glutaryl-phenylalanine } \\
p \text {-nitroanilide }\end{array}$ & - \\
\hline Collagen & $2 \cdot 1 \pm 0.5$ & N-CBZ-Proline & - & Glutamyl $p$-nitroanilide & $0 \cdot 2 \pm 0 \cdot 1$ \\
\hline Trypsin & + & N-CBZ-Aspartate & - & Valyl-alanine $p$-nitroanilide & $368 \pm 102$ \\
\hline Chymotrypsin & + & & & $\begin{array}{l}\text { Succinyl-alanyl-alanyl-alanine } \\
p \text {-nitroanilide }\end{array}$ & - \\
\hline Gelatin & - & & & Benzyl-cysteine $p$-nitroanilide & - \\
\hline Elastin-orcein & - & & & Glycyl-proline $p$-nitroanilide & $243 \pm 41$ \\
\hline $\begin{array}{l}\text { Azosoya bean } \\
\text { flour }\end{array}$ & $152 \pm 15$ & & & Benzyl-tyrosine $p$-nitroanilide & - \\
\hline Azocasein & $215 \pm 12$ & & & Lysine $p$-nitroanilide & - \\
\hline Azoalbumin & - & & & Pyrrolidonyl $\beta$-naphthylamide & - \\
\hline \multirow[t]{7}{*}{ Azocoll } & - & & & Alanine $\beta$-naphthylamide & - \\
\hline & & & & Proline $\beta$-naphthylamide & - \\
\hline & & & & Leucine $\beta$-naphthylamide & $18 \cdot 7 \pm 6 \cdot 8$ \\
\hline & & & & Cystine $\beta$-naphthylamide & - \\
\hline & & & & Serine $\beta$-naphthylamide & $0 \cdot 3 \pm 0 \cdot 2$ \\
\hline & & & & Valine $\beta$-naphthylamide & $\overline{-}$ \\
\hline & - & Hint & 1110 pic & $\mathrm{d} \mathrm{h}^{-1}(\mathrm{mg} \text { dry wt cells })^{-1}$ & \\
\hline
\end{tabular}

assimilated the products of casein hydrolysis. Protein breakdown continued after growth ceased but the rate of peptide uptake was markedly reduced, resulting in a progressive accumulation of these hydrolysis products.

Effect of nitrogen source on protease and arylamidase activities. B. fragilis grew with ammonia, peptone or casein as nitrogen source, with growth being fastest on ammonia (Table 2). Analysis of fermentation products showed that spent medium did not contain branched-chain VFA and that only marginally higher levels of acetate and propionate were present after growth on 


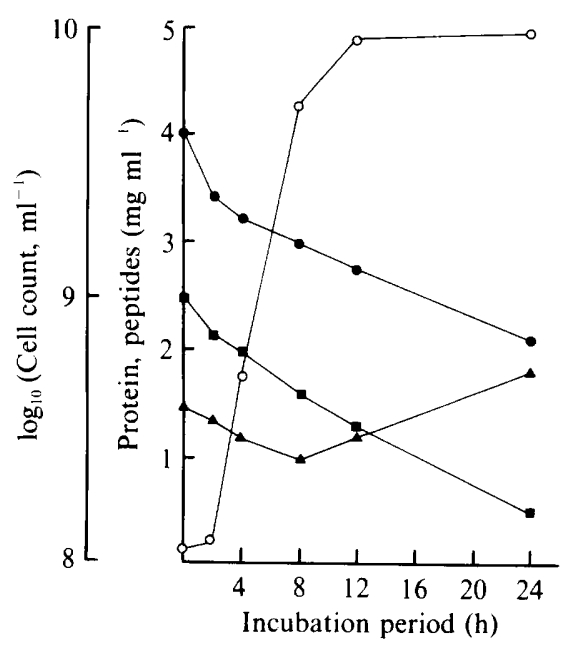

Fig. 2

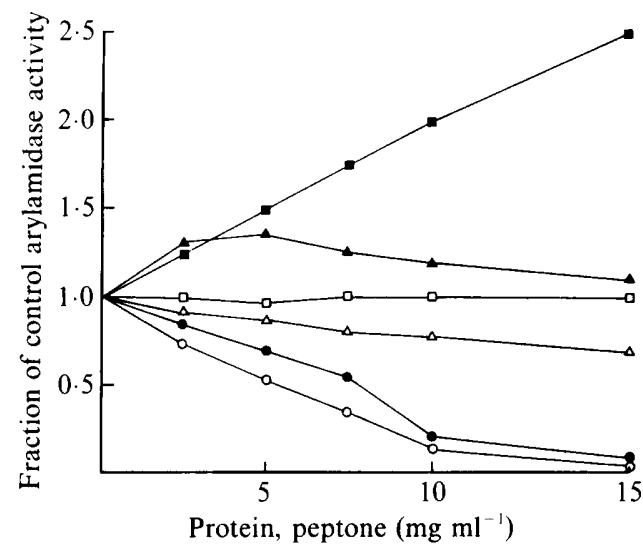

Fig. 3

Fig. 2. Breakdown of casein by $B$. fragilis during growth in batch culture. $\bullet$, Total protein and peptides; $\boldsymbol{\square}$, casein; $\boldsymbol{\Delta}$, TCA-soluble peptides; $O$, cell numbers. Results are the means of duplicate experiments.

Fig. 3. Effect of protein and peptides on arylamidase activities of B. fragilis proteases. Data are shown as fractions of control activities. Closed symbols, LPNA activities; open symbols, VAPNA activities. Cell-bound arylamidase activities are shown in the presence of BSA $(\square, \square)$, casein $(\Delta, \triangle)$ and peptone $(\bullet, 0)$.

\section{Table 2. Effects of nitrogen source on growth and protease activities}

Bacteria were grown in batch culture on mineral salts medium with glucose $(1 \%, w / v)$ as carbon source and either ammonia, peptone or casein (all $0.5 \%$ ) as nitrogen source. Samples were taken for measurement of protease and arylamidase activities during the exponential phase of growth. Results are the means of three experiments $\pm \mathrm{SD}$.

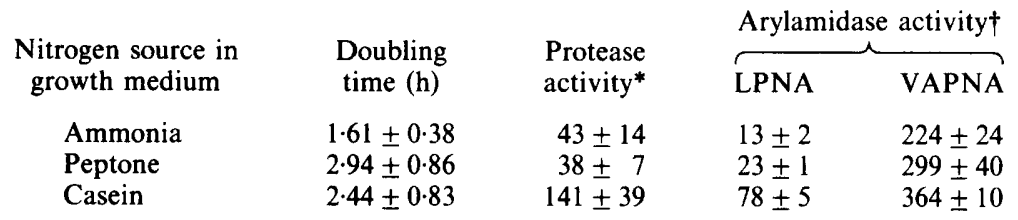

* $\mu \mathrm{g}$ azocasein hydrolysed $\mathrm{h}^{-1}(\mathrm{mg} \text { dry wt cells })^{-1}$.

$\dagger$ nmol $p$-nitroaniline produced $\mathrm{h}^{-1}(\mathrm{mg} \text { dry wt cells })^{-1}$.

peptone or casein. Protease activity was greatest when the bacteria were grown on casein and this was accompanied by a 6-fold increase in leucine arylamidase activity and a $63 \%$ increase in VAPNA hydrolysis compared to ammonia-grown cultures. Glycyl-proline $p$-nitroanilide was not used as an arylamidase substrate in these and subsequent studies since it was found that the enzyme which catalysed the hydrolysis of this substrate was identical to that which hydrolysed VAPNA (unpublished results).

Stimulation of arylamidase activity by protein and peptone. BSA stimulated LPNA hydrolysis by B. fragilis at all concentrations tested (Fig. 3), however no effect on valyl-alanine arylamidase activity was observed. Casein concentrations up to $5 \mathrm{mg} \mathrm{ml}^{-1}$ stimulated leucine arylamidase but higher concentrations had progressively less effect. In contrast, casein $\left(15 \mathrm{mg} \mathrm{m}^{-1}\right)$ inhibited the hydrolysis of VAPNA by up to $30 \%$. The inhibition of both LPNA and VAPNA hydrolysis by peptone was concentration dependent $\left(90 \%\right.$ at $\left.15 \mathrm{mg} \mathrm{ml}^{-1}\right)$. 
Table 3. Effect of haemin on the expression of protease activity

Bacteria were grown on mineral salts medium in batch culture at $37^{\circ} \mathrm{C}$ for $24 \mathrm{~h}$. Glucose $(1 \%$, w/v) was the carbon source and ammonia $(0.5 \%, \mathrm{w} / \mathrm{v})$ was the nitrogen source. Results are the means of two experiments.

\begin{tabular}{|c|c|c|c|c|c|c|c|c|}
\hline \multirow{2}{*}{$\begin{array}{l}\text { Growth } \\
\text { medium }\end{array}$} & \multirow{2}{*}{$\begin{array}{l}\text { Protease } \\
\text { activity* }\end{array}$} & \multicolumn{2}{|c|}{$\begin{array}{l}\text { Arylamidase } \\
\text { activity }{ }^{\dagger}\end{array}$} & \multicolumn{4}{|c|}{ Fermentation products (mM) } & \multirow{2}{*}{$\begin{array}{l}\text { Cell yield } \\
\text { (mg dry wt } \\
\text { cells } \mathrm{ml}^{-1} \text { ) }\end{array}$} \\
\hline & & LPNA & VAPNA & Acetate & Propionate & Fumarate & Succinate & \\
\hline With haemin & 181 & 56 & 840 & $9 \cdot 0$ & $4 \cdot 0$ & ND & $2 \cdot 3$ & 0.96 \\
\hline No haemin & 174 & 54 & 789 & $4 \cdot 1$ & ND & $3 \cdot 4$ & $0 \cdot 2$ & $0 \cdot 19$ \\
\hline & & $\begin{array}{l}{ }^{*} \mu \mathrm{g} \mathrm{az} \\
\dagger \mathrm{nmol} \\
\mathrm{ND}, \mathrm{No}\end{array}$ & $\begin{array}{l}\text { ssein hyd } \\
\text { itroanili } \\
\text { letected. }\end{array}$ & $\begin{array}{l}\text { ysed h- } \\
\text { produc }\end{array}$ & $\begin{array}{l}\mathrm{mg} \text { dry wt } \\
\mathrm{h}^{-1}(\mathrm{mg} \mathrm{d}\end{array}$ & $\begin{array}{l}\text { lls) })^{-1} \\
\text { wt cells) }\end{array}$ & & \\
\hline
\end{tabular}

Table 4. Effect of growth rate and nutrient limitation on protease and arylamidase activities

Bacteria were grown under carbon limitation $\left(5 \mathrm{~g}_{\text {glucose }} 1^{-1}, 1 \mathrm{~g} \mathrm{NH}_{4} \mathrm{Cl}^{-1}\right)$ and nitrogen limitation ( $15 \mathrm{~g} g l u c o s e ~^{-1}, 1 \mathrm{~g} \mathrm{NH}_{4} \mathrm{Cl}^{-1}$ ) at various dilution rates. Anaerobic conditions were maintained by sparging cultures with a gas mixture containing $10 \% \mathrm{CO}_{2}, 10 \% \mathrm{H}_{2}$ and $80 \% \mathrm{~N}_{2}$. Results are the means of four experiments.

\begin{tabular}{|c|c|c|c|c|c|c|c|c|c|c|}
\hline \multirow{3}{*}{$\begin{array}{l}\text { Dilution } \\
\text { rate, } D \\
\left(\mathrm{~h}^{-1}\right)\end{array}$} & \multirow{3}{*}{$\begin{array}{c}\text { Limiting } \\
\text { nutrient }\end{array}$} & \multirow{2}{*}{\multicolumn{2}{|c|}{ Protease activity* }} & \multirow{3}{*}{$\begin{array}{l}\text { Specific } \\
\text { cell-bound } \\
\text { protease } \\
\text { activity } \dagger\end{array}$} & \multicolumn{4}{|c|}{ Arylamidase activity $\ddagger$} & \multirow{2}{*}{\multicolumn{2}{|c|}{$\begin{array}{c}\begin{array}{c}\text { Specific } \\
\text { cell-bound } \\
\text { arylamidase } \\
\text { activity }\end{array} \\
.\end{array}$}} \\
\hline & & & & & Extra & $\overbrace{}^{\text {acellular }}$ & Cell- & $\overbrace{}^{- \text {bound }}$ & & \\
\hline & & Extracellular & Cell-bound & & LPNA & VAPNA & LPNA & VAPNA & LPNA & VAPNA \\
\hline 0.03 & $\begin{array}{l}\text { Ammonia } \\
\text { Glucose }\end{array}$ & $\begin{array}{l}25 \\
32\end{array}$ & $\begin{array}{l}73 \\
98\end{array}$ & $\begin{array}{r}88 \\
108\end{array}$ & $\begin{array}{l}\text { ND } \\
\text { ND }\end{array}$ & $\begin{array}{l}29 \\
29\end{array}$ & $\begin{array}{l}26 \\
31\end{array}$ & $\begin{array}{l}248 \\
207\end{array}$ & $\begin{array}{l}32 \\
34\end{array}$ & $\begin{array}{l}303 \\
227\end{array}$ \\
\hline $0 \cdot 06$ & $\begin{array}{l}\text { Ammonia } \\
\text { Glucose }\end{array}$ & $\begin{array}{l}24 \\
24\end{array}$ & $\begin{array}{l}74 \\
96\end{array}$ & $\begin{array}{r}91 \\
110\end{array}$ & $\begin{array}{l}\text { ND } \\
\text { ND }\end{array}$ & $\begin{array}{l}28 \\
34\end{array}$ & $\begin{array}{l}23 \\
27\end{array}$ & $\begin{array}{l}249 \\
139\end{array}$ & $\begin{array}{l}28 \\
31\end{array}$ & $\begin{array}{l}308 \\
160\end{array}$ \\
\hline $0 \cdot 12$ & $\begin{array}{l}\text { Ammonia } \\
\text { Glucose }\end{array}$ & $\begin{array}{l}14 \\
25\end{array}$ & $\begin{array}{l}204 \\
105\end{array}$ & $\begin{array}{l}215 \\
148\end{array}$ & $\begin{array}{l}\text { ND } \\
\text { ND }\end{array}$ & $\begin{array}{l}23 \\
29\end{array}$ & $\begin{array}{l}75 \\
40\end{array}$ & $\begin{array}{l}306 \\
185\end{array}$ & $\begin{array}{l}79 \\
56\end{array}$ & $\begin{array}{l}322 \\
260\end{array}$ \\
\hline $0 \cdot 18$ & $\begin{array}{l}\text { Ammonia } \\
\text { Glucose }\end{array}$ & $\begin{array}{l}\text { ND } \\
\text { ND }\end{array}$ & $\begin{array}{l}248 \\
110\end{array}$ & $\begin{array}{l}223 \\
170\end{array}$ & $\begin{array}{l}\text { ND } \\
\text { ND }\end{array}$ & $\begin{array}{l}\text { ND } \\
\text { ND }\end{array}$ & $\begin{array}{r}116 \\
31\end{array}$ & $\begin{array}{l}336 \\
176\end{array}$ & $\begin{array}{r}105 \\
78\end{array}$ & $\begin{array}{l}305 \\
270\end{array}$ \\
\hline & & $\begin{array}{l}{ }^{*} \mu \mathrm{g} \mathrm{az} \\
\dagger \mu \mathrm{g} \mathrm{az} \\
\ddagger \mathrm{nmol} \\
\S \mathrm{nmol} \\
\mathrm{ND}, \mathrm{N}\end{array}$ & $\begin{array}{l}\text { zocasein hyd } \\
\text { zocasein hyd } \\
p \text {-nitroanili } \\
p \text {-nitroanili } \\
\text { ot detected. }\end{array}$ & $\begin{array}{l}\text { lrolysed } h^{-1} \\
\text { lrolysed } h^{-1} \\
\text { ne produced } \\
\text { ne produced }\end{array}$ & $\begin{array}{l}\mathrm{ml}^{-1} \\
(\mathrm{mg} \mathrm{dr} \\
\mathrm{d} \mathrm{h}^{-1} \mathrm{ml} \\
\mathrm{d} \mathrm{h}^{-1}(\mathrm{~m}\end{array}$ & $\begin{array}{l}\text { y wt cells) } \\
1^{-1} \text {. } \\
\text { ng dry wt }\end{array}$ & $\begin{array}{l})^{-1} \\
\text { cells) } \\
-1\end{array}$ & & & \\
\hline
\end{tabular}

Effect of ammonia, VFA and haemin on the expression of protease and arylamidase activities. The human large gut is characterised by the presence of high levels of VFA and ammonia. Experiments were therefore undertaken to ascertain whether these metabolites had an effect on protease activity. Increasing ammonia concentrations from $1 \mathrm{~mm}$ to $100 \mathrm{~mm}$ in growth media repressed valyl-alanine arylamidase and azocasein hydrolysing activity by $47 \%$ and $19 \%$ respectively. Leucine arylamidase was unaffected, however. High concentrations of VFA (up to $80 \mathrm{mM}$ ) neither stimulated nor repressed protease activity. When haemin was omitted from the growth medium, cell yields were greatly reduced and fumarate accumulated in the medium (Table 3). Cell-bound protease specific activities were completely unaffected, however.

Continuous culture experiments. Extracellular protease activity was observed in continuous cultures of $B$. fragilis grown at low dilution rates $\left(D=0.03 \mathrm{~h}^{-1}-D=0.12 \mathrm{~h}^{-1}\right)$ under both carbon and nitrogen limitation. This accounted for about $25 \%$ of total protease activity in the cultures (Table 4). Extracellular LPNA hydrolysis was never found, although low levels of extracellular 
VAPNA-hydrolysing activity occurred (23-24 nmol $p$-nitroaniline produced $\mathrm{h}^{-1} \mathrm{ml}^{-1}$ ). Cellbound protease activity was strongly growth-rate-dependent, particularly in nitrogen-limited cultures. Leucine arylamidase activity was stimulated 3 -fold by increasing the growth rate from a generation time of $23.1 \mathrm{~h}$ to that of $3.8 \mathrm{~h}$, but valyl-alanine arylamidase activity appeared to be little affected.

\section{DISCUSSION}

Although $B$. fragilis proteases were completely cell-bound during active growth in batch culture, substantial quantities of proteolytic activity were released from stationary phase bacteria. In this respect, $B$. fragilis proteases behaved similarly to those of the rumen species $B$. ruminicola (Hazlewood \& Edwards, 1981).

Proteolytic activity in human faeces is cell-bound and extracellular (Macfarlane et al., 1986). The release of proteolytic activity from older cells of $\boldsymbol{B}$. fragilis suggests that colonic bacteroides may contribute towards extracellular proteolysis in the gut, as well as that associated with the bacteria.

A comparatively restricted range of proteins and synthetic substrates was hydrolysed by $B$. fragilis, indicating that the proteases of this bacterium are different to those of other Bacteroides spp. For example, BSA is hydrolysed by the proteases of $B$. ruminicola (Hazlewood \& Edwards, 1981 ) and collagen is degraded by the extracellular trypsin-like proteases of $B$. melaninogenicus (Gibbons \& Macdonald, 1961) and by other black-pigmented Bacteroides species (van Steenbergen \& de Graaff, 1986). The apparent weak hydrolysis of collagen by $B$. fragilis was probably not a true collagenolytic activity, since many general proteases can hydrolyse parts of the collagen molecule outwith the helical domain of the protein (Siefter \& Harper, 1971).

The inability of $B$. fragilis to degrade collagen and elastin is perhaps not surprising since these proteins are efficiently hydrolysed by pancreatic proteases in the small intestine and in normal circumstances they are unlikely to be readily available as substrates for colonic bacteria. The pancreatic proteases trypsin and chymotrypsin do enter the colon in substantial amounts, however, and are extensively degraded by gut bacteria (Bohe et al., 1983). These proteins may well serve as substrates for $\boldsymbol{B}$. fragilis type organisms in vivo. Indeed, we have found that $\boldsymbol{B}$. fragilis can grow with trypsin or chymotrypsin as sole nitrogen source (unpublished results).

Studies on casein utilization showed that the protein was hydrolysed during exponential and stationary phases of growth. TCA-soluble peptides only accumulated in the culture medium in the stationary phase, however, suggesting that protein utilization by actively growing bacteria was limited by the rate of casein hydrolysis rather than by the rate of peptide assimilation.

Azocasein- and LPNA-hydrolysing activities were higher in bacteria grown on casein compared to those grown on peptone or ammonia (Table 2). BSA, a protein which is refractile to hydrolysis by $B$. fragilis proteases, also stimulated leucine arylamidase activity (Fig. 3) but when BSA was washed from the cells, this stimulation was abolished (data not shown), indicating that the effect was reversible, as well as non-specific with respect to the stimulating protein. The reason for stimulation of protease and leucine arylamidase activity is unclear. A possibility is that exogenous protein associates with and stabilizes the outer membrane thereby facilitating the activity of outer membrane proteases. Casein appeared to be less stimulatory than BSA, which together with the peptone inhibition data suggests that there was inhibition of LPNA arylamidase activity by casein hydrolysis products.

$B$. fragilis proteases were constitutive and were formed under a variety of growth conditions. Experiments to determine factors that affected protease activity showed that more protease was produced at high growth rates in continuous cultures, and that ammonia, VFA or haemin did not significantly affect proteolysis. In contrast to $B$. fragilis, ammonia has been shown to inhibit proteolysis in other Gram-negative bacteria such as Vibrio alginolyticus (Long et al., 1981), Pseudomonas aeruginosa (Whooley et al., 1983), Aeromonas hydrophila (Pansare et al., 1985) and Butyrivibrio fibrisolvens (Cotta \& Hespell, 1986).

It is not clear whether the proteases of $B$. fragilis type bacteria have an important nutritional function, since colonic contents contain large amounts of both ammonia and protein. However, 
proteolytic activity has been related to pathogenicity in some bacteria, such as the clostridia (Hentges \& Smith, 1985), Pseudomonas aeruginosa (Morihara \& Homma, 1985) and Legionella (Gul'nik et al., 1986). Amongst the bacteroides, the proteases of B. melaninogenicus and $B$. gingivalis are thought to be associated with periodontal disease (Hausmann \& Kaufman, 1969; Yoshimura et al., 1984).

Although part of the normal gut flora (Finegold et al., 1983), B. fragilis group organisms such as $B$. vulgatus, $B$. thetaiotaomicron, $B$. distasonis and particularly $B$. fragilis itself can be pathogenic, and are frequently isolated from clinical specimens (Dowell \& Lombard, 1981). In view of the role in the aetiology of disease of proteolytic enzymes produced by other bacteria, it is possible that the proteases formed by colonic bacteroides may similarly be a contributing factor towards their pathogenicity in man.

\section{REFERENCES}

APPEL, W. (1984a). Elastase. In Methods of Enzymatic Analysis, 2nd edn, vol. 2, pp. 1041-1045. Edited by H. U. Bergmeyer. London: Academic Press.

APPEL, W. (1984b). Peptidases. In Methods of Enzymatic Analysis, 2nd edn, vol. 2, pp.949-978. Edited by H. U. Bergmeyer. London: Academic Press.

APPEL, W. (1984c). Carboxypeptidases. In Methods of Enzymatic Analysis, 2nd edn, vol. 2, pp.986-999. Edited by H. U. Bergmeyer. London: Academic Press.

Bohe, M., Borgstrom, S. \& Ohlsson, G. K. (1983). Determination of immunoreactive trypsin, pancreatic elastase and chymotrypsin in extracts of human feces and ileostomy drainage. Digestion 27, 8-15.

Cotta, M. A. \& Hespell, R. B. (1986). Proteolytic activity of the ruminal bacterium Butyrivibrio fibrisolvens. Applied and Environmental Microbiology 52, $31-58$.

Cruickshank, R. (1965). Medical Microbiology. Edinburgh: Livingstone.

Cummings, J. H., Gibson, S. A. W., Allison, C. \& Macfarlane, G. T. (1986). Proteolytic activities of colonic Bacteroides. Proceedings of the XIV International Congress of Microbiology, 309.

Dowell, V. R. \& Lombard, G. L. (1981). Pathogenic members of the Genus Bacteroides. In The Prokaryotes, pp. 1425-1449. Edited by M. P. Starr, H. Stolp, H. G. Truper, A. Balows \& H. H. Schlegel. New York: Springer Verlag.

Finegold, S. M., SutTER, V. L. \& Mathisen, G. E. (1983). Normal indigenous intestinal flora. In $\mathrm{Hu}$ man Intestinal Microflora in Health and Disease, pp. 3-31. Edited by D. J. Hentges. London: Academic Press.

Gherardini, F., Babcock, M. \& Salyers, A. A. (1985). Purification and characterization of two $\alpha$ galactosidases associated with catabolism of guar gum and other $\alpha$-galactosides by Bacteroides ovatus. Journal of Bacteriology 161, 500-506.

GibBons, R. J. \& Macdonald, J. B. (1961). Degradation of collagenous substrates by Bacteroides melaninogenicus. Journal of Bacteriology 81, 614-621.

Gul'NiK, S. V., Yusupova, M. P., Lavrenova, G. I., Tartakovsky, I. S., Prozorovsky, S. V. \& StEPANOV, V. M. (1986). Proteinases of Legionella: Phenylalanineaminopeptidase of $L$. pneumophila. Journal of General Microbiology 132, 387-392.

Hausmann, E. \& Kaufman, E. (1969). Collagenase activity in a particulate fraction from Bacteroides melaninogenicus. Biochimica et biophysica acta 194, 612-615.

Hazlewood, G. P. \& Edwards, R. (1981). Proteolytic activities of a rumen bacterium, Bacteroides ruminicola R8/4. Journal of General Microbiology 125, 1115.

Hentges, D. J. \& Smith, L. Ds. (1985). Hydrolytic enzymes as virulence factors of anaerobic bacteria. In Bacterial Enzymes and Virulence, pp.105-119. Edited by I. A. Holder. Boca Raton, Florida : CRC Press.

Holdeman, L. V., Cato, E. P. \& Moore, W. E. C. (eds) (1977). Anaerobic Laboratory Manual, 4th edn. Blacksburg, Virginia: VPI Anaerobe Laboratory.

KeIth, S. M. \& HerberT, R. A. (1983). Dissimilatory nitrate reduction by a strain of Desulfovibrio desulfuricans. FEMS Microbiology Letters 18, 55-59.

Loesche, W. J., Socransky, S. S. \& Gibbons, R. J. (1964). Bacteroides oralis, proposed new species isolated from the oral cavity of man. Journal of Bacteriology 88, 1329-1337.

Long, S., Mothibelli, M. A., RobB, F. T. \& Woods, D. R. (1981). Regulation of extracellular alkaline protease activity by histidine in a collagenolytic Vibrio alginolyticus strain. Journal of General Microbiology 127, 193-199.

Macfarlane, G. T. \& Allison, C. (1986). Utilization of protein by human gut bacteria. FEMS Microbiology Ecology 38, 19-24.

Macfarlane, G. T., Allison, C. \& Cummings, J. H. (1985). Distribution of proteolytic activity in the intestinal contents of man. Journal of Applied Bacteriology 59, xviii-xix.

Macfarlane, G. T., Cummings, J. H. \& Allison, C. (1986). Protein degradation by human intestinal bacteria. Journal of General Microbiology 132, 16471656.

Macfarlane, G. T. \& Englyst, H. N. (1986). Starch utilization by the human large intestinal microflora. Journal of Applied Bacteriology 60, 195-201.

MacY, J. M. \& Probst, I. (1979). The biology of gastrointestinal Bacteroides. Annual Reviews in Microbiology 33, 561-594.

Morihara, K. \& Homma, J. Y. (1985). Pseudomonas proteases. In Bacterial Enzymes and Virulence, pp.41-79. Edited by I. A. Holder. Boca Raton, Florida: CRC Press.

Pansare, A. C., Venugopal, V. \& Lewis, N. F. (1985). A note on nutritional influence on extracellular 
protease synthesis in Aeromonas hydrophila. Journal of Applied Bacteriology 58, 101-104.

SALYERS, A. A. (1984). Bacteroides of the human lower intestinal tract. Annual Reviews in Microbiology 38, 293-313.

Salyers, A. A. \& O'Brien, M. (1980). Cellular location of enzymes involved in chondroitin sulfate breakdown by Bacteroides thetaiotaomicron. Journal of Bacteriology 143, 772-780.

Salyers, A. A., Palmer, J. K. \& Wilkins, T. D. (1977). Laminarinase ( $\beta$-glucanase) activity in $\mathrm{Bac}$ teroides from the human colon. Applied and Environmental Microbiology 33, 1118-1124.

SiefTER, S. \& HARPER, E. (1971). The Collagenases. In The Enzymes, vol. 3, pp.649-697. Edited by P. D. Boyer. New York: Academic Press. van Steenbergen, T. S. M. \& De Graaff, J. (1986). Proteolytic activity of black-pigmented Bacteroides strains. FEMS Microbiology Letters 33, 219-222.

Whooley, M. A., O'Callaghan, J. A. \& McloughLIN, A. J. (1983). Effect of substrate on the regulation of exoprotease production by Pseudomonas aeruginosa ATCC 10145. Journal of General Microbiology 129, 981-988.

Yoshimura, F., Nishikata, M., SUzuki, T., Hoover, C. I. \& Newbrun, E. (1984). Characterization of a trypsin-like protease from the bacterium Bacteroides gingivalis isolated from human dental plaque. Archives of Oral Biology 29, 559-564. 